\title{
SECURITIZATION OF EU ENERGY POLICIES IN THE GAS MARKETS
}

\section{Moshenets I. O.}

\section{INTRODUCTION}

This chapter aims to explore the steadily evolving changes in EU energy policies aimed at ensuring higher level of energy security by preparing EU member-countries to scenarios of sudden gas supply disruptions.

Since the oil crisis of 1973, the topic of energy security gained importance as the primary goal of foreign energy affairs. The classic definition of energy security, given by Daniel Yergin, states that it is "availability of sufficient energy supply at affordable prices". Nevertheless, the energy security problem encompasses many dimensions of the problem which can be analyzing using completely different theoretical assumptions. Also, such explanatory diversity was partially the reflection of extending basic theoretical debates in the discipline of international relations (IR) in the area of foreign energy affairs $^{2}$. In short, we can observe in the literature the tendency to distinguishing two basic approaches. The first one, corresponding with IR realist theories, concentrates on strategic usage of energy resources in expanding power of political actors or their conflicts over the control on these resources. The second one, being the reflection of idealist IR theoretical thinking, emphasizes the role of economic rationality in political decision-making and multilateral cooperation in the framework of well-functioning market arrangements ${ }^{3}$.

The distinction between these realist and idealist interpretations plays an important role in discussions about EU external energy policy. The

${ }^{1}$ Yergin D. Ensuring energy security. Foreign Affairs. 2006. Vol. 85. Iss. 2. P. 69-82.

2 Cesnakas G. Energy resources in foreign policy: a theoretical approach. Baltic Journal of Law and Politics. 2010. Vol. 3. Iss.1. P. 30-52

3 Česnakas G. Energy resources in foreign policy: a theoretical approach. Baltic Journal of Law and Politics. 2010. Vol. 3. Iss.1. P. 30-52; Metais R. Ensuring energy security in Europe: The EU between a market-based and a geopolitical approach. College of Europe Studies: EU Diplomacy Papers. 2013. Iss. 3.31 p.; Stoddard E. Reconsidering the ontological foundations of international energy affairs: realist geopolitics, market liberalism and a politico-economic alternative. European Security. 2013.Vol. 22, Iss. 4. P. 437-463. 
basic principles of common EU energy policies during the 1990s and 2000 s were the establishment of independent supervisory entities for market regulation and demonopolization of markets by unbundling of vertically-integrated monopolies and ensuring third-party access to energy infrastructure ${ }^{4}$. However, during the last years scholars noticed, that predominantly liberal market-oriented EU's approach toward its external suppliers and managing its energy import was supplemented by some geostrategic measures aimed at resolving political problems connected with gas supply security. This securitization of EU energy policies was targeting Russia's position on EU energy markets or forcing it to change its behavior in complying with the standards set by the EU energy law" ${ }^{5}$. Andersen et. al. called this emerging tendency in EU policies "new liberal mercantilism",

Three gas conflicts between Russia and Ukraine over gas transit to the EU through the Ukrainian GTS were key events that have contributed to the growing securitization of EU's common energy policy. The 2006 and 2009 disputes culminated in short-term gas supply interruptions through Ukraine to Europe during the wintertime. The crisis in spring 2014 was caused by Russia's annexation of Crimea and its support of pro-Russian separatists in Donbas region. In terms of gas transit, this conflict posed rather a potential threat of supply disruptions in the medium term. Nevertheless, it had perhaps the biggest influence on the securitization of EU energy policies leading to the idea of creating an Energy Union.

Firstly this idea appeared in April 2014 in an op-ed of Polish Prime Minister Donald Tusk, published in the Financial Times ${ }^{7}$. This article outlined a plan for further European integration for reaching a higher level of EU collective energy security. His proposal was based on six main ideas: 1) the creation of a mechanism for the joint purchase of natural gas for European countries; 2) ensuring the existence of a "solidarity" mechanism of mutual insurance between EU countries in the event of a gas supply crisis; 3 ) financing of infrastructure construction in the most dependent on Russian import countries; 4) use of shale gas and coal for emergency replacements of natural gas in times of crisis; 5) signing agreements on the import of liquefied gas to Europe from the

${ }^{4}$ Herweg N. European Union Policy-Making: The Regulatory Shift in Natural Gas Market Policy. Palgrave Macmillan. 2017. P. 76-88.

${ }^{5}$ Siddi M. The role of power in EU-Russia energy relations: The interplay between markets and geopolitics. Europe-Asia Studies. 2018. Vol. 70. Iss. 10. P. 1552-1571.

6 Andersen S., Goldthau A., Sitter N. From Low to High Politics? The EU's Regulatory and Economic Power In Andersen S., Goldthau A.; Sitter N. (eds.) Energy Union: Europe's New Liberal Mercantilism? Palgrave Macmillan. 2017. P. 13-26.

Tusk D. A united Europe can end Russia's energy stranglehold. URL: https://www.ft.com/content/91508464-c661-11e3-ba0e-00144feabdc0 
United States or Australia; 6) strengthening integration in the framework of the Energy Community ${ }^{8}$.

Many of these ideas were reflected in "European Energy Security Strategy" issued in May $2014^{9}$. President of the European Commission Jean-Claude Juncker included the Energy Union as one of the ten priorities of his political program at the beginning of his tenure in December 2014 ${ }^{10}$. In February 2015 European Commission presented a visionary document entitled "A framework strategy for a resilient Energy Union with a forward-looking climate change policy" 11 . In March of the same year Commission received a mandate from the European Council for its implementation ${ }^{12}$. Maroš Ševčović, which was appointed VicePresident of the European Commission for the Energy Union, presented the plans for this formation, saying that "This is the largest energy project since the European Coal and Steel Community",13.

To explain the evolving nature of discussed changes, we need to trace developments in particular dimensions of securitization of EU energy policies. We distinguish four basic mechanisms of discussed "securitization turn": solidarity response on sudden gas supply disruptions; financing of infrastructure projects from common EU budgetary sources; control of European Commission over the contractual activities of member states with third countries; creation of institutional foundation for common EU energy diplomacy.

\section{Evolution of the mechanism of solidarity response to gas supply crises}

The Gas Security Directive $2004^{44}$ was based on several institutional innovations. First of all, it initiated the creation of a Gas Coordination Group, a platform for coordinating actions in the EU in the situations of

8 Tusk D. A united Europe can end Russia's energy stranglehold. URL: https://www.ft.com/content/91508464-c661-11e3-ba0e-00144feabdc0

9 European Energy Security Strategy. URL: https://eur-lex.europa.eu/legalcontent/EN/TXT/?uri=celex\%3A52014DC0330

${ }_{10}$ Juncker J.-C. A new start for Europe: my agenda for jobs, growth, fairness and democratic change: political guidelines for the next European Commission. P.6-7. URL: https://ec.europa.eu/commission/sites/beta-political/files/juncker-political-guidelinesspeech_en.pdf

${ }^{11}$ A framework strategy for a resilient Energy Union with a forward-looking climate change policy. URL: https://eur-lex.europa.eu/legal-content/EN/ TXT/?uri=CELEX:52015DC0080

Will EU states play ball on Energy Union? URL: https://www.euractiv.com/section/energy/news/will-eu-states-play-ball-on-energy-union Will EU states play ball on Energy Union? URL: https://www.euractiv.com/section/energy/news/will-eu-states-play-ball-on-energy-union

${ }_{14}$ Council Directive 2004/67/EC of 26 April 2004 concerning measures to safeguard security of natural gas supply. URL: https://eur-lex.europa.eu/legalcontent/EN/TXT/?uri=CELEX\%3A32004L0067 
significant supply disruptions. This institution includes representatives of member states and sectoral organizations within the gas sector under the leading role of European Commission.

Secondly, the directive established the so-called "supply standard" - the criteria for scanarios in which consumers in a particular EU country must be protected from sudden problems with gas supply. The document identified three following cases: partial interruptions in gas supply during a certain period, the duration of which should be determined by each member state separately; especially cold periods within the nationally determined peak period; periods of particularly high gas consumption during the times of extremely cold weather, which statistically occur every 20 years.

The conducting of policies in this area was left solely to the discretion of member states. The list of their obligations included the definition of a national standard for the size of strategic gas reserves; publication of national regulations on the procedure for counteracting crisis situations; bilateral cooperation with other EU members on gas storage facilities; expanding the list of users with guaranteed gas supply in times of crisis by small and medium enterprises.

Other duties of the EU member states imposed by the described directive concerned informing the commission on such parameters as the volume of gas storage facilities or the impact of the measures taken to implement the directive on market competition. Information on longterm natural gas supply contracts concluded by public and private companies, based in particular country, should also be communicated to the European Commission. The similar obligation of informing Brussels was also relevant to regulatory documents aimed at attracting investments in various parts of the gas industry.

Based on the information received from member states, the European Commission was responsible for creating a common perspective on gas import to the EU, taking into account the differences of supply sources between different regions. According to the directive, European Commission was needed to focus on such factors and indicators as level of infrastructural connectivity between individual countries, the state of operation of gas storage facilities, the overall share of import gas supply from third countries in framework of long-term contacts, availability of possible alternatives for their emergency replacement.

New regulation on security of gas supply in $2010^{15}$ contained four basic ideas. First, it required EU Member States to set up a special

${ }^{15}$ Regulation (EU) No 994/2010 of the European Parliament and of the Council of 20 October 2010 concerning measures to safeguard security of gas supply and repealing Council Directive 2004/67/EC. URL: https://eur-lex.europa.eu/legalcontent/EN/ALL/?uri=CELEX\%3A32010R0994 
national-level institution responsible for coordinating energy security policy. The directive required the introduction of national preventive action plans and emergency response plans for such institutions. The aims of preventive action plans are in risk evaluation and in preparing list of actions preventing the occurrence of undesirable supply situations (including detailed reglamentation of public service obligations (PSO) by largest suppliers for households' market). Emergency response plans determine the measures of mitigating the results of supply disruptions after their occurring.

Secondly, the new regulation, unlike the previous directive, set clearer requirements for supply standards. Countries were required to provide protected consumers with gas for seven days during periods of extreme cold; for at least 30 days in case of increased demand for natural gas; and for at least 30 days in case of an unforeseen disruption of supply.

Third, in addition to the supply standard, regulation added another indicator - the infrastructure standard. It was calculated based on the socalled formula "N -1 ". It describes the technical capacity of the gas infrastructure to meet the demand for the gas in the calculated area in the case of a malfunction of one of the largest infrastructure facilities during a day of exceptionally high gas demand, which occurs with a statistical error every 20 years. This formulated technical capacity, respectively, should not be less than the total gas demand during this simulated day of the extreme situation within the analyzed area. The calculation took into account all types of infrastructure, such as distribution networks, interconnectors, gas processing plants, liquefied natural gas terminals and underground gas storage facilities.

Fourth, the 2010 regulation presupposed a system of regular risk assessment within the framework of preventive action and emergency response plans. Such an assessment was to be carried out within 18 months of the adoption of the plans and then updated every two years.

It should be noted that, in addition to strengthening the general requirements for energy security, the 2010 regulation changed the nature of cooperation in this area between the states and the European Commission, strengthening the Brussel's control. This is seen in the procedure set out in the document for agreeing the provisions of both types of plans between the states and the Commission. Even in case of some disagreements from the side of national governments, Brussels could still force its recommendations to be taken into account effectively in the long run. 
In October 2014, the European Commission released a report on the implementation of the 2010 gas directive ${ }^{16}$. This document identified several shortcomings of the existing at that time response system to gas supply crisis. To these shortcomings belonged foremost different approaches of EU member states to the operationalization of the provisions of the supply standard, which led to an uneven level of protection of certain categories of consumers in different countries. The information collection system remained imperfect, because specific data was lacking in some required parameters in the reports. Bilateral interconnection between different countries has improved, but not as much as expected. The inability to achieve a higher level of international coordination under the existing at that time conditions of the 2010 directive was a fact that was particularly emphasized in the report ${ }^{17}$.

The draft of the new regulation 2017 was based on two key ideas. The first one was the creation of a full-fledged mechanism of solidarity response to supply disruptions, when the neighbours of each member state can provide it with gas supplies gas in an emergency for a commercial fee. The second idea was to transfer risk assessment and response planning mechanisms to the regional level ${ }^{18}$.

However, in its final version ${ }^{19}$ regulation kept the creation of preventive action and emergency response plans at the national level, without merging them into regional plans, as the European Commission initially wanted. Nevertheless, these national security documents should have instead a special mandatory "regional" section that regulates interaction with neighbours in the scenario of the supply disruption. This chapter had to be prepared and agreed jointly by all countries in a specific risk group with the participation of the European Commission, allowing thus better coordination of member states activities. These regional sections, in particular, were to provide opportunities for joint

\footnotetext{
${ }^{16}$ Report on the implementation of Regulation (EU) 994/2010 and its contribution to solidarity and preparedness for gas disruptions in the EU. URL: https://op.europa.eu/en/publication-detail/-/publication/7b93db36-551c-11e4-a0cb01aa75ed71a1/language-en

${ }^{17}$ Report on the implementation of Regulation (EU) 994/2010 and its contribution to solidarity and preparedness for gas disruptions in the EU. URL: https://op.europa.eu/en/publication-detail/-/publication/7b93db36-551c-11e4-a0cb01aa75ed71a1/language-en

18 Simon F. Member states challenge regional gas "solidarity" plan. URL: https://www.euractiv.com/section/energy/news/member-states-challenge-regionalgas-solidarity-plan/

${ }^{19}$ Regulation (EU) 2017/1938 of the European Parliament and of the Council of 25 October 2017 concerning measures to safeguard the security of gas supply and repealing Regulation (EU) No 994/2010. URL: https://eur-lex.europa.eu/legalcontent/EN/TXT/?uri=celex\%3A32017R1938
} 
access of countries at risk to gas storage facilities and liquefied natural gas terminals of their neighbours.

The need for better coordination among neighbouring countries required the creation of subregional platforms for technical communication on gas supply-related issues. Thirteen groups were formed based on the source of possible supply risks. Membership in each risk groups is not exclusive, and therefore one country can be a member of different groups. For example, Germany is a member of seven groups out of thirteen. Such division principle allowed creation of a more flexible crisis response system, better adapted for responding to different types of supply problems and not focused exclusively on the Russian direction (although it was the threat of Russian gas supply cuts which was the main motivation for EU reforms in this area).

In addition to these two key changes, the final version of the regulation detailed some other provisions of the draft, in particular the principles of solidarity assistance for a fee. Following the revisions of the draft decision, new terms appeared, such as the pan-European definition of protected consumers ("solidarity protected consumers") and the concept of "emergency supply corridors" - infrastructure routes by which countries should avoid the worst consequences of gas supply.

It should be noted that the 2017 regulation expanded the powers of ENTSO-G, in particular in terms of monitoring international risks and the possibility of changing the composition of groups depending on the current realities of energy markets. Here we can see a possible compromise between the member states and the European Commission. Despite some supranationaliation of energy security policies, a lot of control powers were given not to Commission, but to the intergovernmental institution consisting of national energy regulators.

\section{Common financing of infrastructure projects}

The need for prioritization of infrastructure construction was regarded as important issue by the European Commission already in the 90-s when of a common pan-European infrastructure program TEN-E was created.

However, in the 2000s this program had very limited success. The selection criteria were not elaborated, and each national or local executive body could make proposals to include the projects in the list. Coupled with limited funding for its operation, this factor made TEN-E almost ineffective. As of 2011, the list of TEN - E included 568 priority projects but annual budget for the support of their construction was only 
about 20 million euros. Therefore European help was visible only in financing of technological assessments of particular projects ${ }^{20}$.

The 2008 financial crisis has changed the situation with infrastructure financing in Europe. The European Commission has prepared a significant financial package to stimulate post-crisis economic recovery. This was especially important for President of the European Commission Jose Manuel Barroso, since he was preparing for his re-election for a second term. Thus, energy infrastructure appeared among the political priorities of the Economic Plan for the Recovery of Europe, presented by the Commission in November $2008^{21}$. It has noted that Brussels is expected to allocate about 5 billion euros from the community's financial resources to intensify the construction of energy infrastructure for the period 2009-2014.

Another important point for the EU's more active involvement in the construction of gas transport infrastructure was the February 2011 European Council summit on energy issues. Among the conclusions of the summit was a request to the Commission to rethink the forms and mechanisms of infrastructural financing ${ }^{22}$. To accomplish this task, in June 2011 the Commission proposed a "Connecting Europe Facility" program ${ }^{23}$. Its plan presupposed the allocation of 40 billion euros from the EU medium-term budget for 2014-2020 to create new energy, transport and digital infrastructure. The energy part of the programme accounted of 9.1 billion euros. Despite the considerable increase of available funds, CEF covered only a small part of the total needs, because, according to the European Commission, only the improvement of gas infrastructure over the budget period required 70 billion euros (and 140 billion euros for electricity) ${ }^{24}$.

In 2011 was adopted a new 10-year plan TEN-E with active involvement of European Network of Transmission System Operators for Gas (ENTSO-G), national energy regulators and all other relevant

${ }^{20}$ Buchan D. Expanding the European dimension in energy policy: the Commission's latest initiatives. P. 29-30. URL: https://www.oxfordenergy.org/publications/expandingthe-european-dimension-in-energy-policy-the-commissions-latest-initiatives/

21 A European Economic Recovery Plan. URL: https://eur-lex.europa.eu/legalcontent/EN/ALL/?uri=CELEX\%3A52008DC0800

${ }_{22}$ Energy summit runs low on sparks. URL: https://www.euractiv.com/section/energy/news/energy-summit-runs-low-on-sparks/

23 Proposal for a Regulation of the European Parliament and of the Council establishing the Connecting Europe Facility. URL: https://eurlex.europa.eu/LexUriServ/LexUriServ.do?uri=COM:2011:0665:FIN:EN:PD

24 Leaked EU paper maps energy infrastructure black spots. URL: https://www.euractiv.com/section/energy/news/leaked-eu-paper-maps-energyinfrastructure-black-spots/ 
stakeholers. The new ten-year plan envisaged the development of four priority gas infrastructure corridors ${ }^{25}$. The first was called "North-South gas interconnections in Western Europe" (NSI West Gas) focused on supply diversification in the region from Portugal to Germany and from Spain to Ireland. The "North-South Gas Interconnections in CentralEastern and South-Eastern Europe" direction (NSI East Gas) focused on improving gas connections in the region between the Baltic, Adriatic, Black, Aegean and Black Seas. Under the Southern Gas Corridor (SGG), the EU relied on infrastructure to supply gas to Europe from the Caspian Basin, Central Asia, the Middle East and the Eastern Mediterranean. The Baltic Energy Market Connection Plan (BEMIP Gas) was supposed to end the isolation of the three Baltic States and Finland from the rest of the European gas transmission system and eliminating their complete dependence on Russia as the sole importer of gas.

In 2013, the European Commission in its regulation ${ }^{26}$ determined publishing lists of so-called "Projects of Common Interest" as the basic procedure for selecting priority infrastructure projects. This list had to be updated on two-year basis. As of December 2020, four editions of "Projects of Common Interest" have already been published - in 2013, $2015,2017^{27}$ and $2019^{28}$. Progress in the implementation of projects was officially tracked in annual Commission's reports under title "State of the Energy Union" ${ }^{, 29}$.

There were three main sources of pan-European financial resources that could be used by gas infrastructure projects. The first of them was already mentioned CEF program, proposed in 2011. In 2014, it replaced the TEN-E funding mechanism as a basic form of support for new

25

Trans-European

Networks

for

Energy.

URL:

https://ec.europa.eu/energy/topics/infrastructure/trans-european-networks-energy_en

${ }^{26}$ Regulation (EU) No 347/2013 of the European Parliament and of the Council of 17 April 2013 on guidelines for trans-European energy infrastructure and repealing Decision No 1364/2006/EC and amending Regulations (EC) No 713/2009, (EC) No 714/2009 and (EC) No 715/2009, 25.04.2013. URL: https://eur-lex.europa.eu/legalcontent/EN/TXT/?uri=celex\%3A32013R0347

Key cross border infrastructure projects. URL: https://ec.europa.eu/energy/topics/infrastructure/projects-common-interest/key-crossborder-infrastructure-projects_en

${ }^{28}$ Commission publishes 4 th list of Projects of Common Interest - making energy infrastructure fit for the energy union. URL: https://ec.europa.eu/info/news/commissionpublishes-4th-list-projects-common-interest-making-energy-infrastructure-fit-energyunion-2019-oct-31_en

292020 report on the State of the Energy Union pursuant to Regulation (EU) 2018/1999 on Governance of the Energy Union and Climate Action. URL: https://eurlex.europa.eu/legal-content/EN/TXT/?qid=1602743359876\&uri=COM:2020:950:FIN 
infrastructure projects in the $\mathrm{EU}^{30}$. Another option was the European Structural and Investment Funds (ESIF), which funded projects in seven core areas, including the Energy Union and the environment. The third way to attract financing were loans from the European Bank for Reconstruction and Development (EBRD) and the European Investment Bank (EIB).

\section{Control over foreign energy trade}

The establishment of Commission's control mechanisms over the energy contracts of EU member states was the result of gradual formation. The first attempt to achieve this goal began in February 2011, when the European Commission presented the first draft of its decision ${ }^{31}$. Its proposal was based on three main principles. First, it advocated for the creation of a legal instrument for the mandatory exchange of information between member states. This exchange presupposed them to provide the Commission with information about their new infrastructure investments or trade agreements with third countries, which after that could be accessable to other EU members. Secondly, the European Commission has proposed a regime for monitoring the compliance of these intergovernmental agreements with EU energy legislation. It was expected to make it mandatory for the member states to obtain Commission's conclusions on this compliance before signing the intergovernmental agreements. And thirdly, the European Commission pretended to obtain the right of its representatives to be present in negotiations with third countries on energy supply contracts.

The reaction of most EU member states was traditionally negative toward Commission's ambitions of expanding its control powers ${ }^{32}$. Therefore, after passing full legislature procedure, the final version of the document $^{33}$ adopted in 2012 appeared very compromising. First, the decision allowed countries to provide information on their

${ }^{30}$ Gökce M. Energy Transitions and the Future of Gas in the EU: Subsidise or Decarbonise. Palgrave Macmillan. 2020. P. 103.

${ }^{31}$ Proposal for a Decision of the European Parliament and of the Council setting up an information exchange mechanism with regard to intergovernmental agreements between Member States and third countries in the field of energy. URL: https://eurlex.europa.eu/legal-content/EN/ALL/?uri=CELEX\%3A52011PC0540

${ }^{32}$ Batzella F. The Dynamics of EU External Energy Relations: Fighting for Energy. Routledge. 2018. P. 58.

${ }^{33}$ Decision No 994/2012/EU of the European Parliament and of the Council of 25 October 2012 establishing an information exchange mechanism with regard to intergovernmental agreements between Member States and third countries in the field of energy. URL: https://eur-lex.europa.eu/legal-content/EN/ALL/?uri=CELEX\% 3A32012D0994 
intergovernmental agreements retrospectively, once they had been concluded. The existing agreements were to be sent to Brussels without any consequence for their operation. Thus, the Commission's preventive control over the compliance of agreements with European law was no longer discussed. The similar story was with the mandatory participation of Commission's delegations in the negotiations on such agreements member states were allowed to invite representatives of Brussels to their diplomatic events, but this was remained as their discretionary right. In communicating the details of their intergovernmental agreements, countries obtained the right to inform the Commission on what part of the information they provide is confidential and cannot be provided by European officials to other countries. However, the Commission's staff should in any case have had access to these "closed" parts of the agreements, but only for their internal use.

However, the decision allowed the European Commission to monitor the results of its implementation in the form of a special report, which was to be made before December 1, 2016. In its implementation report, the Commission cited the example of South Stream, a Russian pipeline project aimed to bypass the Ukrainian GTS from the south. Even though Kremlin eventually abondoned the project in 2014, Russians already have concluded six intergovernmental agreements with European countries before that time. According to the Commission's analysis, all of them did not comply with European legislation on third party access conditions and unbundling, which created a need to review the entire mechanism of monitoring and control of import agreements with third countries $^{34}$.

In February 2016, the European Commission proposed to revise the 2012 decision and supplement it with a mechanism for preventive coordination of intergovernmental agreements. Such ideas have again sparked discussion in the European Council. The countries of Central and Eastern Europe, most of which were heavily dependent on Russian gas supplies, have called with both hands for the strengthening of the European Commission's control powers in this area. At the other pole, another group of states wanted to keep the competences of national governments in this area free from supranational interference. They referred to the formulation of Part 2 of Art. 194 of the Treaty on the Functioning of the European Union, which preserved the right of

${ }^{34}$ Report from the Commission to the European Parliament, the Council and the European Economic and Social Committee on the application of the Decision 994/2012/EU establishing an information exchange mechanism on intergovernmental agreements between Member States and third countries in the field of energy. URL: https://eur-lex.europa.eu/legal-content/EN/TXT/?uri=CELEX\%3A52016DC0054 
member states to independently determine the composition of their energy mixes and left them all possible solutions in this policy field ${ }^{35}$. After negotiations, a compromise was reached. In June 2016, the Ministers of Energy at a meeting of the EU Council agreed that the mechanism of preventive control of contracts with third countries should relate only to the gas sector and not to electricity. In April 2016, the final decision was made.

Under the terms of the new regulation ${ }^{36}$, by 3 August 2017, EU Member States were obliged to notify the Commission about their intergovernmental agreements, and the Commission was allowed to comment within 9 months after analyzing their compliance with EU law. The standard of confidentiality was similar to that approved in 2012: the European Commission had to provide all contractual information, which was not indicated by countries as confidential, to other states in a secure electronic form. In the case of a country exercising the right to confidentiality, it was only allowed to submit a general statement of the agreement (subject, purpose, duration, scope and period of implementation). In this case Commission was still given full access to all information, but representatives of other EU member states could not access the confidential parts of agreements. The Commission was also tasked with developing a model template for energy treaties by May 2018 in consultation with EU member countries for improving their overall compliance with European law in the future.

\section{Institutional basis of common energy diplomacy}

Until 2006, the EU's external energy relations were predominantly aimed at achieving two interlinked political goals. The first one was the proliferation of market-oriented legal rules creating broad regional areas for the protection of international investments in energy industry. Another goal was to provide technical assistance to less developed countries to prepare them to liberalization of energy policies.

During the June summit of the European Economic Community in 1990, the Dutch Prime Minister Ruud Lubbers proposed the creation of a broader international platform for energy trade. Lubbers' plan gradually evolved into the idea of an "Energy Charter", which was signed in

35 Thaler P., Pakalkaite V. Governance through real-time compliance: the supranationalisation of European external energy policy. Journal of European Public Policy. 2021.Vol. 28. Iss. 2. P. 13.

${ }^{36}$ Decision (EU) 2017/684 of the European Parliament and of the Council of 5 April 2017 on establishing an information exchange mechanism with regard to intergovernmental agreements and non-binding instruments between Member States and third countries in the field of energy and repealing Decision No 994/2012/EU. URL: https://eur-lex.europa.eu/legal-content/EN/TXT/?uri=celex:32017D0684 
1991 as a broad declaration of principles on liberalized energy trading. In 1994, a more detailed Energy Charter Treaty ${ }^{37}$ was signed, which provided specific mechanisms for liberalizing the markets of the signatory countries. The Energy Charter Treaty focused on guarantees for the protection of foreign investments, a mechanism for resolving commercial disputes, requirements and standards for the safety of energy transportation, and measures to reduce the burden on the environment.

Technical assistance has become another important area of EU diplomatic activity in the international arena. Almost immediately after the collapse of the USSR, several technical assistance programs were created for third countries. The longest-serving of them was INOGATE. This program was launched in 1993. In 1999, a agreement on INOGATE was signed at the summit in Kyiv establishing the central coordinating body of this organization. In 2000, the INOGATE Secretariat was launched in Kyiv, which was later supplemented by an office in Tbilisi. During its existence in 1993-2016, INOGATE funded 69 programs worth more than $\$ 141$ million $^{38}$.

At that time, the Balkan region played a special role in the EU's external activities in the field of energy. In 1995-2004, the EU supported financially the operation of the Black Sea Energy Center with an office in Sofia, Bulgaria. Its activities aimed to promote market reforms and find opportunities to improve the energy connection of the Balkan region with $\mathrm{EU}^{39}$. In 2005, an agreement was signed in Athens on the establishment of the Energy Community ${ }^{40}$, which, in addition to the EU, included eight countries of the Balkan Peninsula. Moldova, Ukraine and Georgia later joined the organization, and Romania and Bulgaria have transformed their membership since joining the EU in 2007. The Energy Community Treaty obliged the signatory countries to implement several European regulations, including 2003 Second Gas Directive which has later been replaced in their obligations by 2009 Third Gas Directive.

Despite EU's active work in the Balkans and the post-Soviet space, the Russian Federation has remained a key energy partner of the EU in recent decades. The EU-Russia Energy Dialogue was established in October 2000 at a bilateral summit in Paris. Despite apparent progress in

37 The Energy Charter Treaty. URL: https://www.energycharter.org/process/energycharter-treaty-1994/energy-charter-treaty/

38 Overview of INOGATE Projects: All Projects. URL: http://www.inogate.org/projects?lang=en

${ }^{39}$ Winrow G. M. Energy security in the Black Sea region: economic interdependence or commercial and political rivalry? Southeast European and Black Sea Studies. 2002. Vol. 2. Iss. 2. P. 137.

40 Treaty establishing Energy Community. URL: https://www.energycommunity.org/legal/treaty.html 
building the institutional format of this bilateral energy dialogue during 2000s, its main goal, namely Russia's ratification of the Energy Charter Treaty, was not achieved ${ }^{41}$. Russian aggressive actions in Ukraine in 2014 lead to frozing of further institutionalization of bilateral dialogue.

The autumn 2011 communication of the European Commission on external energy relations ${ }^{42}$ became a starting point for the formation of a full-fledged European energy diplomacy. The document advocated for the development of the EU's external energy policy, which was envisiged to be based on five priorities: building the external dimension of the internal energy market; strengthening partnerships for "secure, sustainable and competitive energy"; improving access to sustainable energy for developing countries; better implementation of EU policy objectives outside the Union. The communication expressed many ideas that were mostly present in the official EU discourse before, but this document, in its quest to create a coherent vision of EU energy diplomacy, could claim to be the first EU full-fledged strategy in this policy field.

Decision of the European Council summit in February 2011 initiated the creation of separate specialized institutional structures aimed at developing solutions to common European energy diplomacy and therefore to integrate energy issues into EU foreign activities. An Energy Diplomacy Network was established within the structure of European External Action Service based on its Directorate for Multilateral Relations and Global Issues. It has unified experts working under the overall coordination to work on countries and regions identified as important for EU energy security ${ }^{43}$.

Also, the European Commission established a Strategic Group for International Energy Cooperation in 2012. It consisted of the Ministers of Energy and Foreign Affairs of the Member States, as well as representatives of the European External Action Service. The institution was called upon to function as a platform for discussions to identify common priorities for certain initiatives or regions. According to the European Commission's 2013 report on the implementation of its communication on energy diplomacy in 2011, in the first year of its existence alone, the platform hosted five meetings focusing on energy

41 Talseth L.-C. The Politics of Power: EU-Russia Energy Relations in the 21st Century. Palgrave Macmillan. 2017. P. 218-219.

${ }^{42}$ On security of energy supply and international cooperation - "The EU Energy Policy: Engaging with Partners beyond Our Borders". URL: https://ec.europa.eu/transparency/regdoc/rep/1/2011/EN/1-2011-539-EN-F1-1.Pdf

${ }^{43}$ Bocse A.-M. International Networks: Advocacy and EU Energy Policy-Making. Palgrave MacMillan, 2020. P.55. 
relations with Ukraine, China, the Southern Mediterranean and the Eastern Partnership ${ }^{44}$. Nevertheless, even at that stage, the lack of information about national energy activities abroad was identified by the Commission as a problem that hinders more effective policy coordination on this issue between different member states.

The importance of improving European coordination was stressed in 2014 European Energy Security Strategy ${ }^{45}$. In 2015 foreign affairs ministers of EU member states in Council conclusions adopted EU Energy Diplomacy Action Plan ${ }^{46}$. This policy document was concentrated on achieving four basic tasks: 1) strengthen strategic quidance through high-level engagement; 2) establish and further develop energy cooperations and dialogues; 3) support efforts to enhance global energy architecture and multilateral initiatives; 4) strengthen common messages and energy diplomacy capacities.

In 2016 European Commission issued EU strategy for liquid natural gas (LNG) and gas storage ${ }^{47}$. This document recognized problems with energy dependence on one import source for much of the territory of East-Central Europe. One of the three chapters of this strategy was dedicated to EU role in international gas markets. Developing diplomatic connections with LNG exporters (Algeria, Qatar, Nigeria, US etc.) and increasing cooperation with other big LNG importers (Japan, South Korea) were considered priorities in this policy field.

\section{CONCLUSIONS}

In conclusion, it should be noted that EU has gradually developed its energy security instruments by responding to crises that have arisen permanently on the continent and were mainly related to the security of gas supply. These situations have opened up a window of opportunity for the European Commission for formulating proposals for strengthening centralized coordination of national energy policies. Several EU member states were initially skeptical of such Commission initiatives, seeing

44 Implementation of the Communication on Security of Energy Supply and International Cooperation and of the Energy Council Conclusions of November 2011. P. 5. URL: https://data.consilium.europa.eu/doc/document/ST-13642-2013-INIT/en/pdf

${ }^{45}$ Energy security: Commission puts forward comprehensive strategy to strengthen security of supply. URL: https://ec.europa.eu/commission/presscorner/detail/en/ IP_14_606

${ }^{46}$ Council conclusions on energy diplomacy. URL: https://www.consilium.europa.eu/ en/press/press-releases/2015/07/20/fac-energy-diplomacy-conclusions/

${ }^{47}$ Communication from the Commission to the European Parliament, the Council, the European Economic and Social Committee and the Committee of the Regions on an EU strategy for liquefied natural gas and gas storage. URL: https://ec.europa.eu/energy/ sites/ener/files/documents/1_EN_ACT_part1_v10-1.pdf 
them as a threat to the market-oriented policy paradigm and as an attempt by the Commission to expand its powers. However, crises have increased public concern about supply cuts and intensified advocacy efforts at the supranational level of other EU members who were more vulnerable to unforeseen supply disruptions. These factors have forced liberally oriented member states to take energy security issues seriously, gradually agreeing to certain compromises. In such evolutionary way the security instruments of common European energy policy have steadily emerged even in the case of some political disagreement about their need inside EU.

\section{SUMMARY}

This chapter aims to explore the steadily evolving changes in EU energy policies aimed at ensuring higher level of energy security by preparing EU member countries to scenarios of sudden gas supply disruptions. During the last decade predominantly liberal marketoriented EU's approach toward its external suppliers and managing its energy import was supplemented by some geostrategic measures aimed at resolving political problems connected with gas supply security. EU has gradually developed its energy security instruments by responding to crises that have arisen permanently on the continent and mainly related to security of gas supply. These situations have opened up a window of opportunity for the European Commission for formulating proposals for strengthening centralized coordination of national energy policies. We distinguish four basic security instruments: solidarity response on sudden gas supply disruptions; financing of infrastructure projects from common EU budgetary sources; control of European Commission over the contractual activities of member states with third countries; creation of institutional foundation for common EU energy diplomacy.

\section{REFERENCES}

1. 2020 report on the State of the Energy Union pursuant to Regulation (EU) 2018/1999 on Governance of the Energy Union and Climate Action. URL: https://eur-lex.europa.eu/legalcontent/EN/TXT/?qid=1602743359876\&uri=COM:2020:950:FIN

2. A European Economic Recovery Plan. URL: https://eurlex.europa.eu/legal-content/EN/ALL/?uri=CELEX\%3A52008DC0800

3. A framework strategy for a resilient Energy Union with a forwardlooking climate change policy. URL: https://eur-lex.europa.eu/legalcontent/EN/TXT/?uri=CELEX:52015DC0080

4. Andersen S., Goldthau A., Sitter N. From Low to High Politics? The EU's Regulatory and Economic Power In Andersen S., Goldthau A., 
Sitter N. (eds.) Energy Union: Europe's New Liberal Mercantilism? Palgrave Macmillan. 2017. P. 13-26.

5. Batzella F. The Dynamics of EU External Energy Relations: Fighting for Energy. Routledge. 2018. 161 p.

6. Bocse A.-M. International Networks: Advocacy and EU Energy Policy-Making. Palgrave MacMillan, 2020. 245 p.

7. Buchan D.Expanding the European dimension in energy policy:the Commission's latest initiatives.48p. URL:https://www.oxfordenergy.org/publications/expanding-theeuropean-dimension-in-energy-policy-the-commissions-latest-initiatives/

8. Česnakas G. Energy resources in foreign policy: a theoretical approach. Baltic Journal of Law and Politics. 2010. Vol. 3. Iss. 1. P. 30-52.

9. Commission publishes 4th list of Projects of Common Interest making energy infrastructure fit for the energy union. URL: https://ec.europa.eu/info/news/commission-publishes-4th-list-projectscommon-interest-making-energy-infrastructure-fit-energy-union-2019oct-31_en

10.Communication from the Commission to the European Parliament, the Council, the European Economic and Social Committee and the Committee of the Regions on an EU strategy for liquefied natural gas and gas storage. URL: https://ec.europa.eu/energy/sites/ener/files/ documents/1_EN_ACT_part1_v10-1.pdf

11. Council conclusions on energy diplomacy. URL: https://www.consilium.europa.eu/en/press/press-releases/2015/07/20/facenergy-diplomacy-conclusions/

12. Council Directive 2004/67/EC of 26 April 2004 concerning measures to safeguard security of natural gas supply. URL: https://eurlex.europa.eu/legal-content/EN/TXT/?uri=CELEX\%3A32004L0067

13.Decision (EU) 2017/684 of the European Parliament and of the Council of 5 April 2017 on establishing an information exchange mechanism with regard to intergovernmental agreements and nonbinding instruments between Member States and third countries in the field of energy, and repealing Decision No 994/2012/EU. URL: https://eur-lex.europa.eu/legal-content/EN/TXT/?uri=celex:32017D0684

14. Decision No 994/2012/EU of the European Parliament and of the Council of 25 October 2012 establishing an information exchange mechanism with regard to intergovernmental agreements between Member States and third countries in the field of energy. URL: https://eur-lex.europa.eu/legal-content/EN/ALL/?uri=CELEX\%3

A32012D0994 
15.Energy security: Commission puts forward comprehensive strategy to strengthen security of supply. URL: https://ec.europa.eu/commission/presscorner/detail/en/IP_14_606

16. Energy summit runs low on sparks. URL: https://www.euractiv.com/section/energy/news/energy-summit-runs-lowon-sparks/

17. European Energy Security Strategy. URL: https://eurlex.europa.eu/legal-content/EN/TXT/?uri=celex\%3A52014DC0330

18. Gökce M. Energy Transitions and the Future of Gas in the EU: Subsidise or Decarbonise. Palgrave Macmillan. 2020. 301 p.

19. Herweg N. European Union Policy-Making: The Regulatory Shift in Natural Gas Market Policy. Palgrave Macmillan. 2017. 264 p.

20. Implementation of the Communication on Security of Energy Supply and International Cooperation and of the Energy Council Conclusions of November 2011. URL: https://data.consilium.europa.eu/ doc/document/ST-13642-2013-INIT/en/pdf

21. Juncker J.-C. A new start for Europe: my agenda for jobs, growth, fairness and democratic change: political guidelines for the next European Commission. URL: https://www.eesc.europa.eu/resources/ docs/jean-claude-juncker---political-guidelines.pdf

22. Key cross border infrastructure projects. URL: https://ec.europa.eu/energy/topics/infrastructure/projects-commoninterest/key-cross-border-infrastructure-projects_en

23. Leaked EU paper maps energy infrastructure black spots. URL: https://www.euractiv.com/section/energy/news/leaked-eu-paper-mapsenergy-infrastructure-black-spots/

24. Metais R. Ensuring energy security in Europe: The EU between a market-based and a geopolitical approach. College of Europe Studies: EU Diplomacy Papers. 2013. Iss. 3. 31 p.

25. On security of energy supply and international cooperation - "The EU Energy Policy: Engaging with Partners beyond Our Borders". URL: https://ec.europa.eu/transparency/regdoc/rep/1/2011/EN/1-2011-539-ENF1-1.Pdf

26. Overview of INOGATE Projects: All Projects. URL: http://www.inogate.org/projects?lang=en

27. Proposal for a Decision of the European Parliament and of the Council setting up an information exchange mechanism with regard to intergovernmental agreements between Member States and third countries in the field of energy. URL: https://eur-lex.europa.eu/legalcontent/EN/ALL/?uri=CELEX\%3A52011PC0540 
28. Proposal for a Regulation of the European Parliament and of the Council establishing the Connecting Europe Facility. URL: https://eurlex.europa.eu/LexUriServ/LexUriServ.do?uri=COM:2011:0665:FIN:EN:PD

29. Regulation (EU) 2017/1938 of the European Parliament and of the Council of 25 October 2017 concerning measures to safeguard the security of gas supply and repealing Regulation (EU) No 994/2010. URL: https://eur-lex.europa.eu/legal-content/EN/TXT/?uri=celex \%3A32017R1938

30. Regulation (EU) No 347/2013 of the European Parliament and of the Council of 17 April 2013 on guidelines for trans-European energy infrastructure and repealing Decision No 1364/2006/EC and amending Regulations (EC) No 713/2009, (EC) No 714/2009 and (EC) No 715/2009, 25.04.2013. URL: https://eur-lex.europa.eu/legalcontent/EN/TXT/?uri=celex\%3A32013R0347

31. Regulation (EU) No 994/2010 of the European Parliament and of the Council of 20 October 2010 concerning measures to safeguard security of gas supply and repealing Council Directive 2004/67/EC. URL: https://eur-lex.europa.eu/legalcontent/EN/ALL/?uri=CELEX\%3A32010R0994

32.Report from the Commission to the European Parliament, the Council and the European Economic and Social Committee on the application of the Decision 994/2012/EU establishing an information exchange mechanism on intergovernmental agreements between Member States and third countries in the field of energy. URL: https://eurlex.europa.eu/legal-content/EN/TXT/?uri=CELEX\%3A52016DC0054

33. Report on the implementation of Regulation (EU) 994/2010 and its contribution to solidarity and preparedness for gas disruptions in the EU. URL: https://op.europa.eu/en/publication-detail//publication/7b93db36-551c-11e4-a0cb-01aa75ed71a1/language-en

34. Siddi M. The role of power in EU-Russia energy relations: The interplay between markets and geopolitics. Europe-Asia Studies. 2018. Vol. 70. Iss. 10. P. 1552-1571.

35. Simon F. Member states challenge regional gas "solidarity" plan. URL: https://www.euractiv.com/section/energy/news/member-stateschallenge-regional-gas-solidarity-plan/

36. Stoddard E. Reconsidering the ontological foundations of international energy affairs: realist geopolitics, market liberalism and a politico-economic alternative. European Security. 2013.Vol. 22, Iss. 4. P. 437-463.

37. Talseth L.-C. The Politics of Power: EU-Russia Energy Relations in the 21st Century. Palgrave Macmillan. 2017. P. 218-219. 
38. Thaler P., Pakalkaite V. Governance through real-time compliance: the supranationalisation of European external energy policy. Journal of European Public Policy. 2021.Vol. 28. Iss. 2. P. 208-228.

39. The Energy Charter Treaty. URL: https://www.energycharter.org/ process/energy-charter-treaty-1994/energy-charter-treaty/

40. Trans-European Networks for Energy. URL: https://ec.europa.eu/ energy/topics/infrastructure/trans-european-networks-energy_en

41. Treaty establishing Energy Community. URL: https://www.energy-community.org/legal/treaty.html

42. Tusk D. A united Europe can end Russia's energy stranglehold. URL: https://www.ft.com/content/91508464-c661-11e3-ba0e00144feabdc0

43. Will EU states play ball on Energy Union? URL: https://www.euractiv.com/section/energy/news/will-eu-states-play-ballon-energy-union

44. Winrow G. M. Energy security in the Black Sea region: economic interdependence or commercial and political rivalry? Southeast European and Black Sea Studies. 2002. Vol. 2. Iss. 2. P. 137.

45. Yergin D. Ensuring energy security. Foreign Affairs. 2006. Vol. 85. Iss. 2. P. 69-82.

\section{Information about the author:} Moshenets I. O., Postgraduate Student at the Center of Security Studies National Institute of Strategic Studies 18/7, General Almazov str., Kyiv, 01133, Ukraine 